\title{
Romanian National Anthems, Historical, Stylistic and Aesthetic Considerations
}

\author{
Professor PhD CARMEN CHELARU \\ “George Enescu” National University of Arts Iași \\ ROMANIA*
}

I express my gratitude towards my American friend, Lady Cello Bennett, for her substantial help in supervising this English version of my essay.

\begin{abstract}
This text represents an abridgement of an extensive research paper, recently completed, and titled The Song-Symbol, History and Content. About the National Anthems. It has not been long since I wrote about a sensitive subject: that of prejudices in considering and reconsidering history, those which could manipulate (in fact do manipulate!) consciences positively or negatively, and sometimes generate extremist ideas and attitudes (Chelaru, 2017). Following the course of history, a dilemma arose regarding the national anthem, particularly regarding its origins, the circumstances under which a particular anthem was chosen, and above all, comparisons of one anthem to another. From a general point of view, the first observation is that the anthem, especially as it is perceived nowadays in Europe, involves historical meaning, symbols of human communities and nations. As a result, I want to suggest certain improvements towards the current configuration of this musical genre. First I will summarize the history of the Romanian national anthems, beginning with the very first one, adopted during the reign of Alexandru Ioan Cuza, continuing with the monarchic period, then the anthems of communist Romania, and finally the present one, Deșteaptă-te, române! - which is in fact the oldest of all. The main reason I chose this issue does not concern purely academic curiosity; it pursues my entirely subjective interest in the circumstances that prompted Romanians to adopt, over the last century and a half, just these hymns and not others.
\end{abstract}

Keywords: anthem, national, Romanian, Mureșanu, Porumbescu.

\section{Introduction}

Throughout the 18th century, European civilizations - especially Western ones - have accelerated the pace of evolution.

The historian Lucian Boia, in his book Două secole de mitologie națională / Two Centuries of National Mythology, observes about the concepts of nation and national:

"The history of humanity actually involves two histories /.../ During the first (ed. historic period), people lived closely grouped in small communities. Even the great empires, monstrous conglomerates, were composed of local

\footnotetext{
*carmen.chelaru@gmail.com
} 
ethnic groups. /.../ Then, an open world arose, one in which developments occurred faster and faster. This is the modern age. At the middle of the 18th century, these processes accelerated more and more, generation after generation, up until the present day. The traditional structures have cracked and collapsed."1 (Boia, 2012, p. 7)

Beginning with the period of Enlightenment, Europeans entered the modern age, choosing civilization to primitivism, collaboration to confrontation, exchange of ideas and argumentation to violence....

Meanwhile, as a result of the re-drawing of the borders of the various empires, and above all the respective rulers' impositions of forced assimilation of various kinds, people became more conscious of ethnic and cultural affiliations. Thus the spirit of nationalism was born, with all of its consequences.

The philosophers of the 18th century Enlightenment, anticipating the modern age, defined concepts and ideas such as: liberty, progress, tolerance, fraternity, constitutional rule, separation of church and state. To the Christian phrase, "Believe and do not doubt", they replied with sapere aude - "Dare to find out" (Gay, 1996, apud Wikipedia).

The Enlightenment period generated the intellectual and cultural advancement of the 19th century, including liberalism and neoclassicism. Step by step, new ideas and influences penetrated Central and Eastern European social communities as well. In Transylvania, for instance, most of the inhabitants were Romanians. In 1701, a remarkable event took place, with major consequences for the Romanian population: the Greek-Catholic Church was founded. Through this new religious institution, Romanian people were given new opportunities, especially access to education (Chelaru, 2016, p. 33).

While the 18th century had been marked by innovative ideas, the following century saw Europe's territorial, political, and cultural structures radically altered by historic events. People became aware of their ethnic affiliations. As a result, social and national anxiety and conflicts increased throughout the 19th century. Concepts such as homeland, love of country, and patriotism took on increasingly greater importance in the sphere of common life.

This empowerment of nationalism, with its attendant growing number of conflicts, led to, among other things, the adoption of national symbols: flags,

\footnotetext{
1 „Istoria omenirii reunește în fapt două istorii /... / În cea dintâi, oamenii au trăit strâns grupaţi, în comunități restrânse. Chiar marile imperii, conglomerate monstruoase, nu făceau decât să acopere structuri de viaţă predominant locale. /.../ Apoi, lucrurile încep să evolueze spre o lume deschisă, și să se miște din ce în ce mai repede. Aceasta este modernitatea. Proces intrat pe la mijlocul secolului al XVIII-lea într-o fază de accelerare, amplificată până astăzi, generație după generație. Structurile tradiționale s-au fisurat, apoi s-au năruit.”
} 
emblems, seals, slogans, national colours, and national anthems. In time, importance was also placed on other symbols: national animals and plants, founding personalities, costumes and objects (including musical instruments like Russian balalaika and gusla, or the Scottish bagpipe), dances (Hungarian czardas, Italian tarantella or saltarello, Romanian hora) etc. All these symbols carry specific meanings, historical background and sentimental content, even when the ascribed attributes are not always entirely rational or realistic.

In the 19th century, people had acquired the habit of expressing their joy, as well as their dissatisfaction, by gathering in crowds that grew increasingly large over the years. Under these circumstances music became more and more important, and a special repertoire appeared for cheering, stimulating courage and initiative, popular support, war songs, etc. When such music was associated with a historical event favouring the life of a particular community, it became a patriotic song.

Nation, Spirit of nationalism, National Specific -

the circumstances these concepts emerged in Europe

\begin{tabular}{ll}
\hline $\begin{array}{l}\text { Renaissance } \\
\text { centuries 13th }-17 \text { th }_{/ 1}\end{array}$ & Humanistic Philosophy, Arts, Literature \\
\hline $\begin{array}{l}\text { Enlightenment } \\
\text { centuries 17th/2 - 18th }\end{array}$ & Science, Technique, Economy \\
\hline $\begin{array}{l}\text { Romanticism } \\
\text { 19th century }\end{array}$ & Revolution, Nationalism, Liberalism
\end{tabular}

As the above frame shows, a series of stages in the evolution of Western European civilization, from Renaissance to Romanticism, created favourable conditions for the emergence of spirit of nationalism and the accompanying national symbols.

\section{Short History of Romanian National Anthems}

The first national anthems in the world were adopted in Europe, and some national anthems from other continents have European origins as well. Romanians quickly took up the idea from other nations regarding patriotic repertoire, primarily as a result of the historical events of the 19th century²:

> 1821: The Wallachian Uprising (Southern Romania) against Ottoman rule, led by Tudor Vladimirescu. He issued his first proclamation (January 23),

${ }^{2}$ In the Romanian version of this essay I did not include the following enumeration of historical events, considering it to be known. For foreign readers, however, I consider it necessary in order to better understand the Romanian historical context in close connection with the European one. 
which included references to Enlightenment principles, expressed his commitment to peace with the Ottomans, and banishment of the Phanariote Princes ${ }^{3}$.

$>$ 1848: Democratic Revolution in Moldavia and Wallachia, against medieval structures.

> 1859: Union between Moldavia and Wallachia, under Prince Alexandru Ioan Cuza.

> 1866: Prince Alexandru Ioan Cuza abdicated. Principatele Unite (United Principalities) became The United Principalities of Romania, under Prince Carol of Romania (Karl of Hohenzollern-Sigmaringen) ${ }^{4}$.

$>$ 1878: Romania was proclaimed independent of the Ottoman suzerainty.

$>$ 1881: The Romanian principality was raised to a kingdom and on March 26, Prince Carol became King Carol I of Romania.

$>$ 1918: At the end of World War I, Transylvania and Bessarabia united with the Romanian Kingdom.

$>$ 1920: The union of Transylvania, Maramureș, Crișana and Banat with the Kingdom of Romania was ratified by the Treaty of Trianon.

Consequently, the second half of the 19th century through the beginning of the twentieth represents the most prolific period regarding Romanian patriotic music, written by Romanian musicians Alexandru Flechtenmacher, Ciprian Porumbescu, Gavriil Musicescu, Gheorghe Dima, Ion Vidu, Dumnitru Georgescu-Kiriac and others.

An interesting source of information regarding this issue is Major Marin Sîlea's book Istoria muzicilor militare (History of Military Music), a detailed analysis of the military music phenomenon in the Carpathian-Danubian territory. Regarding Romanian patriotic songs of the mid-19th century, the author observes:

"The authorship of revolutionary songs has always been questioned; poets and the composers tried to hide their identity for reasons of safety and security, and sometimes even out of modesty and solidarity with the people engaged in combat. Also, when a certain song had to circulate «under cover», it was written using Byzantine neume notation, known only to professionals. These were the circumstances surrounding Anton Pann’s song Deșteaptă-te,

3 Phanariotes $=$ members of prominent Greek families in Phanar, the main Greek quarter of Constantinople. Between 1710s and 1821, in Moldavia and Wallachia thirty-one princes, from eleven Greek families of Phanar, ruled the two principalities during the "Phanariote period”.

4 Prince Karl of Hohenzollern-Sigmaringen was elected Ruling Prince (Domnitor) of the Romanian United Principalities on 20th April 1866, after the overthrow of Alexandru Ioan Cuza by a palace coup d'état. After 1878, when Romania became independent, his title was Royal Highness. On March 26th, 1881 he was proclaimed King of Romania. (Wikipedia) 
române! (Awaken, Romanian!) which was born around the time of the revolution of 1848. After a century and a half this song became the Romanian national anthem.” (Sîlea, 2006, p. 35)

\subsection{The Hymn “Awaken, Romanian!” (Deșteaptă-te, române!)}

I want to begin with this song so well-known to Romanians, since it is the current anthem, and at the same time the oldest one among the seven Romanian national anthems, beginning with 1862.

\section{6 (114) Din sînul maicii mele $_{\text {in }}$}

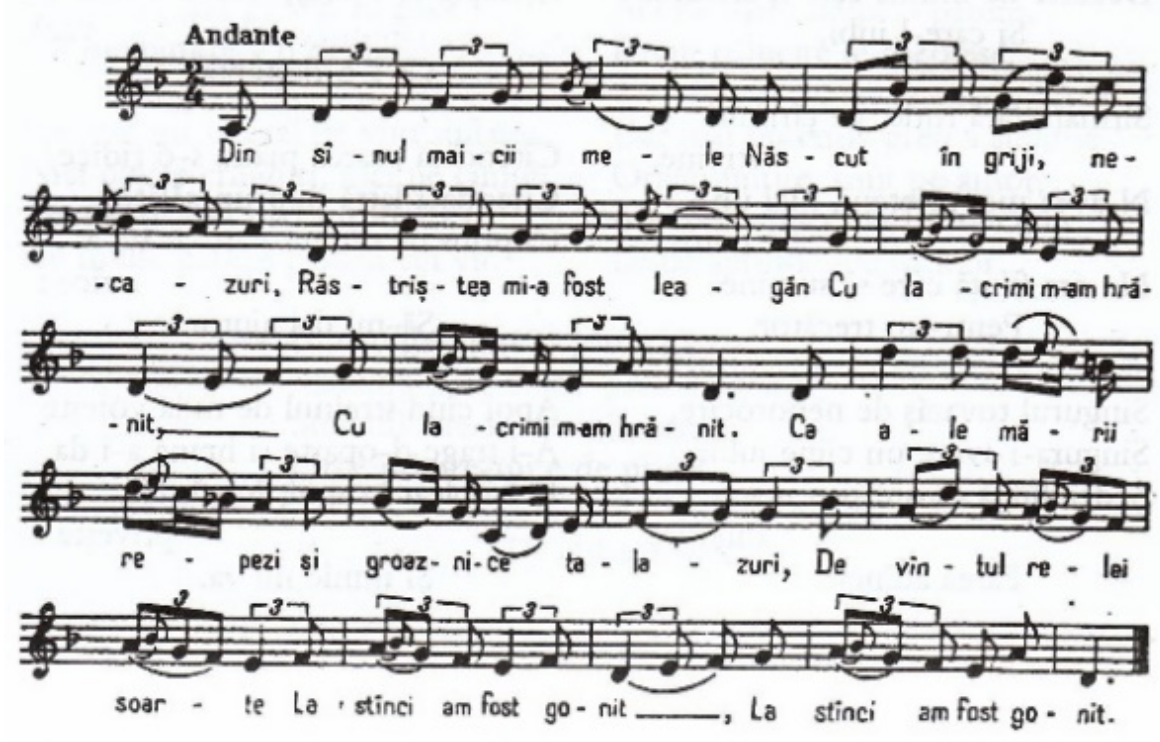

Fig. 1 Anton Pann's romance "From my Mother's Breast”

(Pann, 2009, pp. 134-135)

This song is related to three names: the poet Andrei Mureșanu (or Mureșianu, 1816-1863), the author of the lyrics, and the musicians Anton Pann (1790?-1854) and Grigore Ucenescu (1828-1896), each of whom made a contribution to the music. Grigore Ucenescu, psalter ${ }^{5}$, teacher, and composer, comments on this song as follows:

"The furious year 1848 arriving, the poet [Andrei Mureșanu, o.n.] was looking for a melody that fit with a sonnet /.../ for a soirée. I was singing several songs from which to choose, and when I arrived at «From my Mother's Breast» (Din sânul maicii mele), the poet remained at this one. /.../ On Sunday /.../ Mr. Andrei Mureșanu gave me the lyrics to Awaken, Romanian! I tried it

${ }^{5}$ psalter $=$ cantor of Byzantine/Or ${ }^{\text {th }}$ odox Christian music 
first and the music fit perfectly, so I sang it with my young, loud voice (all the way) to the end. /.../ Since then, the song has become known and familiar, and I have been invited to perform it all over /.../ and to teach other young singers to sing it correctly." (Sîlea, 2006, p. 35) ${ }^{6}$

Thus, the story of this hymn is as follows: Anton Pann composed a religious romance (Fig. 1). In 1848, with or without his knowledge, his apprentice Grigore Ucenescu, at the request of Andrei Mureșanu the poet, adapted the melody to the lyrics.

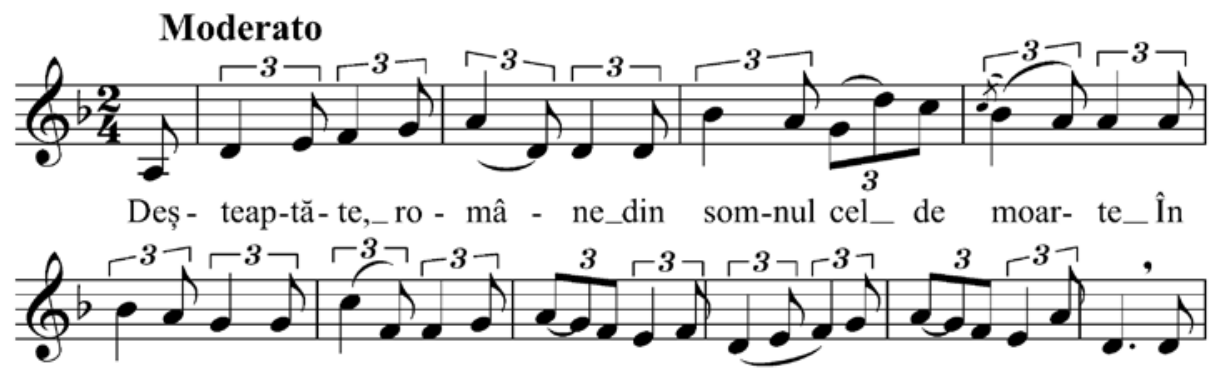

ca-re te'a dân - ci - ră_bar - ba - rii de_ti- rani,__ bar - ba - rii de_ti-rani! A -
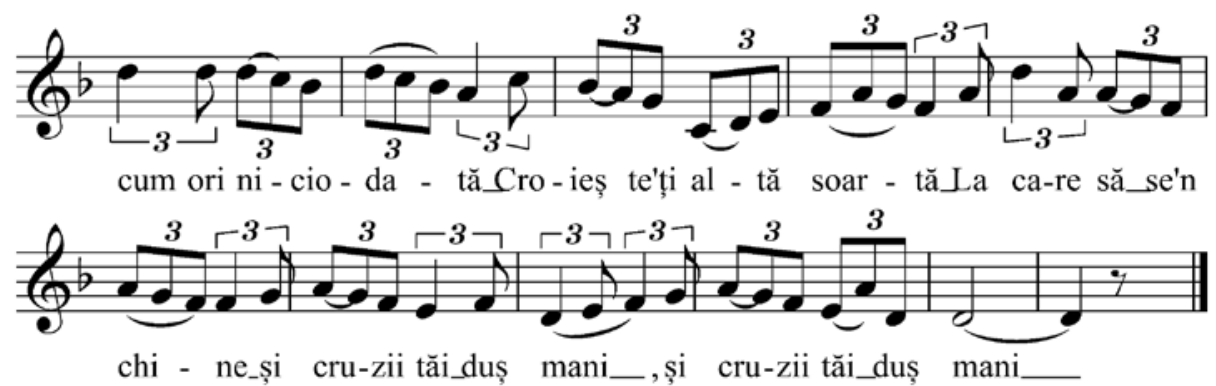

Fig. 2 The patriotic hymn “Awaken, Romanian!”

Grigore Ucenescu’s version,

lyrics by Andrei Mureșanu (Ștefănescu, 1974, p. 79)

Anton Pann died in 1854 without claiming the paternity of this music. It is hard to believe that he was not familiar with the hymn, because Ucenescu declared that the song had been widely circulated after 1848. The only plausible explanation is that Anton Pann did not want his name being

6 ,Sosind furiosul an 1848, poetul [Andrei Mureșanu, n.n.] căuta o melodie după care să compue un sonet care să se cânte /.../ pentru petrecere de seară, /.../. Am cântat multe cântece de probă, iar sosind la următorul cânt, «Din sânul maicii mele» şi cântându-1, a rămas poetul pe lângă această melodie, /.../. În Duminica hotărâtă, /.../ îmi dete Domnul Andrei Mureșanu poezia făcută «Deșteaptă-te Române», îi probăm puține rânduri şi văzând în tot melosul este o minune potrivit, l-am cântat cu vocea mea tânără şi puternică până la fine. /.../ Din ziua aceia cântul «Deșteaptă-te Române» s-au făcut cel mai plăcut şi familiar, iar eu eram poftit în toate părțile /.../ să învăț tinerimea a-l cânta mai bine şi regulat." 
associated with this song. In fact, a century later (in the 1950's and 1960's) the song was perceived to be so subversive that merely humming the tune brought years of imprisonment to those who dared to do it. The same attitude prevailed in the 1980's, when Ceaușescu's propaganda took on paranoid proportions.

Let us look at a few stylistic features of this music. Its structure includes three melodic-rhythmic sections, $a, b, b$, each of them ten bars:

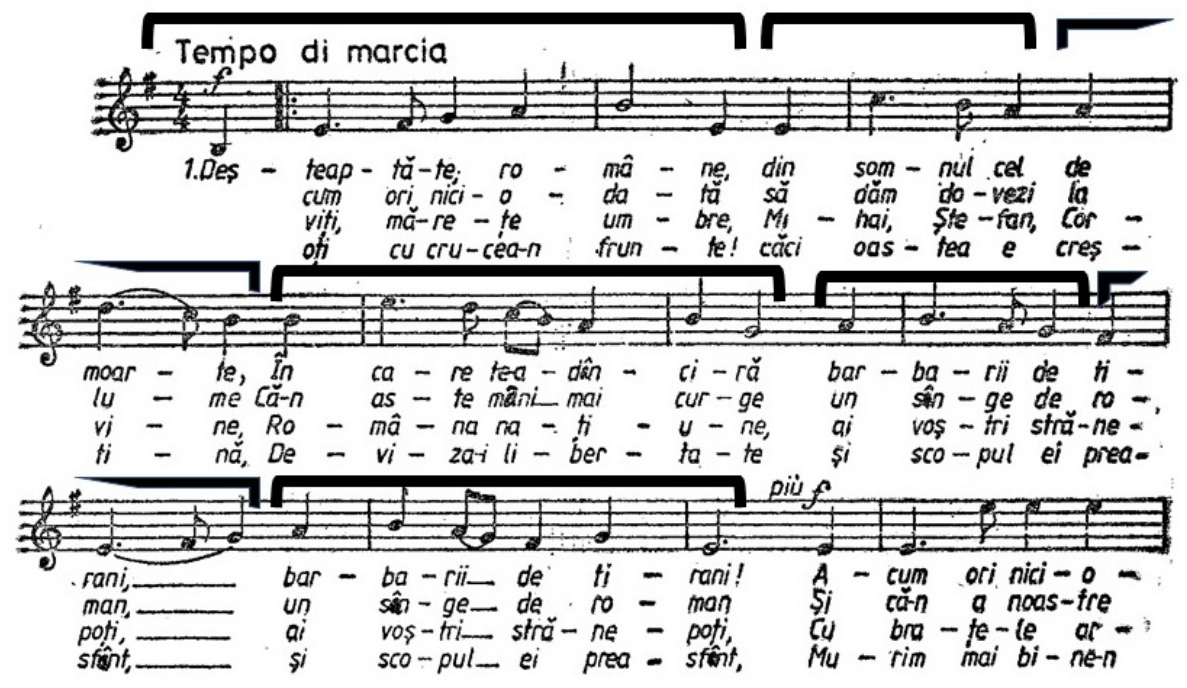

Fig. 3 The song “Awaken, Romanian!” - Section $a$

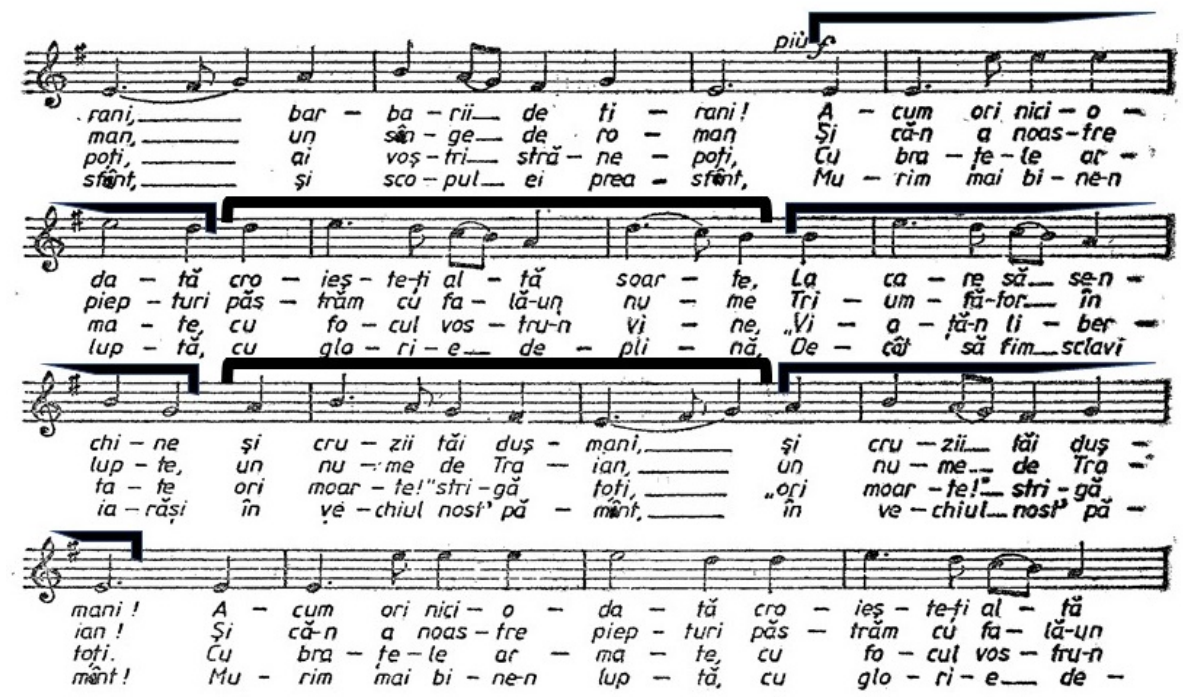

Fig. 4 The song “Awaken, Romanian!”- Section $b$

Section $a$ includes three moments: I. Introduction (bars 1-2). II. Contents\&Climax (bars 3-6), III. Relaxation/Ending (bars 7-10); therefore, the 
bar-plan is $2+4+4$. In figures 3 and 4 the unitary melodic structure, with several variants of the rhythmic motif, is marked:

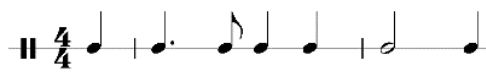

Section $b$ includes three moments as well: I. Climax (bars 11-12), II. Climax emphasis (bars 13-16), III. Epilogue (bars 17-20) - the same structure of $2+4+4$ bars; then section $b$ repeats identically.

Regarding the relationship between the music and the lyrics, it must be mentioned that they have never been separated since the music was fit to the lyrics.

First section includes the first stanza and contains an appeal to action. Section $b$ and the second stanza urge the listeners on to victory:

\section{\begin{tabular}{|l|l|l} 
animation \& mobilization & urge to victory & urge to victory
\end{tabular}}

We are therefore presented with a coherent and symmetric musical construction, where the music merges with the lyrics.

So then why minor?! Would it be an oriental allusion to the Phanariot atmosphere of Romanian society at that time? Or could it be the romance style? ${ }^{7}$ Or perhaps the subversive, conspiratorial tone of the protester's song? The first assumption is hard to prove, so it belongs in the category of speculation.

As for the second one, we must observe that, despite the binary meter, Anton Pann's song has ternary rhythm (Fig. 1). This, together with the minor key, seem to be, we dare say, more appropriate to the pathetic and tearful style of the 19th century romance. Gh. Ucenescu kept for his version the same rhythm (Fig. 2). But Andrei Mureşanu's lyrics are bleak, provocative, even aggressive. We quote below the sixth and seventh stanzas:

A widowed mother from the time of Michael the Great Claims from her sons today a helping hand, And with tears in her eyes curses whomsoever, In such great peril, a traitor would become. Of thunder and of brimstone should they perish Anyone who would flee the glorious place When our land or our mother, with a sorrowful heart, Will ask us to cross through swords and blazing fire. ${ }^{8}$

7 The term romance has the following meanings: "a short instrumental piece with the lyrical character of a vocal romance." (Dolmetsch) and "an emotional attraction or aura belonging to an especially heroic era, adventure, or activity”. (Merriam-Webster)

8 Translated version from https://en.wikipedia.org/wiki/De\%C8\%99teapt\%C4\%83-te,_rom\%C3\%A2ne! 
It was, therefore, necessary to change the character of music, at least rhythmically, from waltz to march ${ }^{9}$. When and who made this change, I did not have the resources and the time to find out.

The third assumption, regarding the conspiratorial tone of this song seems justified if we consider the fate of this symbolic song from its appearance in the mid-19th century to the present. We know less about what happened with this song during the end of the 19th century and the first half of the 20th. However, our parents and grandparents, in fact the recent war generations, were tragically confronted with the choice of singing this hymn. Soon after the communist takeover, it became forbidden de facto, especially during Soviet control of Romania (1944-1965). Then, between 1970 and 1980, a period of "release" took place. After that, the hymn once again became an undeclared taboo. Proof of this fact lies in the choice of this particular song during the people's protests of the winter of 1989, as well as last winter (January-February 2017), when the hymn was once again sung as a protest and exhortation against corruption, lying, and thievery.

The hymn “Awaken, Romanian!” is music intertwined with Romanian national history, laden with strong emotional content. It is music related to initiative, to sudden, dynamic action in troubled times of threats and insecurity. It is less suitable in a socio-political society that wants stability, balance, genuine democracy.

To this I shall add another opinion - that of a non-musician but not an ordinary one: the Romanian philosopher Andrei Pleșu. In his article The National Anthem Psychology (Psihologia imnului național) he comments on the lyrics as a symbol of contemporary Romania.

"I don't pretend that such hymns with strong tragic content do not exist in other countries as well. La Maseillaise itself is not at all an idyllic song. The Italian anthem speaks about awakening too, but it is an awakening already consummated, not a histrionic wake-up for a cataleptic population. From the hymns I have been browsing, one alone, that of Slovakia, demands a providential bolt of lightning to awaken the sleeping people. For the rest, we are dealing mainly with tonic, confident lyrics that respect the original sense of the word «hymn»: a song of praise. /.../ Among all of these, our anthem is one of the darkest and most discouraging. It is a lament, complaining about victimization, lamentation and general adversity - and this in a country that has so recently joined the European Union, whose anthem is the Ode to Joy.” (Pleșu, 2011) ${ }^{10}$

${ }^{9}$ I confess that I've "tried" the song in major key and the result was at least ... hilarious! 10 „Nu pretind că asemenea ịmnuri, cu un pronunțat conținut de obidă națională, nu există şi în alte țări. Marseieza nu e nici ea o melodie campestră. Despre «trezire» se vorbește şi în imnul Italiei, dar despre o trezire deja consumată, nu despre o trezire dorită patetic pentru o populație cataleptică. Din imnurile pe care le-am frunzărit, unul singur, cel al Slovaciei, cere un fulger providențial care să trezească poporul adormit. În rest, avem de-a face, preponderent, cu texte 
Despite the controversial reactions sparked by these sincere and honest confessions, I entirely agree with the statements of the remarkable philosopher, presented as usual in beautiful Romanian language, which shows (if such a thing was necessary!) a genuine patriotic feeling.

The composer Cornel Țăranu made a very interesting discovery, which he presented in "George Enescu" Symposium, on September 3rd, 2017, in Bucharest:

"In 1896, Enescu conceived a few versions for a 'Romanian Suite', mentioned by the musicologist Clemansa Firca in her catalogue. A group of sketches are written in $G$ minor, and a second one in $B$ minor. The first group contains the orchestration of the hymn 'Awaken, Romanian!'. The last version is signed [by the teenaged Enescu, 15 years old at that time, o.n.] and dated 'Paris, December 1896', which means the author considered it has been finished. I completed it with two variations from the previous version, before the section da capo. An episodic theme in Romanian folk-dance style is inserted, announcing the future Rhapsodies.

It seems that Enescu intended to include the hymn 'Awaken, Romanian!' at the end of the 'Romanian Poem'11, but finally, at the suggestion of Princess Bibescu, he has chosen the Romanian Royal Anthem.” (Țăranu, 2017, p. 12)

The composer Cornel Țăranu (www.corneltaranu.com) has therefore reconstituted and completed the orchestral score of "Awaken, Romanian!" included by teenager George Enescu in the sketches at the "Romanian Suite". The work thus completed consists of a short and excellent orchestrated poem (about $8 \mathrm{~min}$.). The first audition took place in Cluj, performed by the students' symphonic orchestra of "Gh. Dima” Academy of Music, conducted by Cristian Sandu (Pascu, 2015). I had the opportunity to listen this music as a recording posted on December 2nd, 2017, by professor Ruxandra Cesereanu on her blog (ruxandracesereanu.wordpress.com).

The music exposes martial, solemn features (on binary rhythm). The main theme is elaborated by orchestration; to the end, the episodic dance theme comes, the one mentioned by the composer Cornel Ţăranu. It is interesting that one of the variations (played by violas, cellos and double-basses) is accompanied by the violins I\&II in ternary rhythm. Was it a compositional effect or did the child Enescu hear Ucenescu's version of the song (the ternary one)? We cannot know. However, it can be deduced from this that the change of character (from waltz to march) took place during 19th century.

tonice, încrezătoare, care respectă sensul originar al termenului imn: cîntec de laudă. (...) Una peste alta, imnul nostru este, prin comparație, dintre cele mai întunecate şi descurajante.

Mizează, plîngăcios, pe victimizare, lamentație şi adversitate generală. Asta într-o țară preluată de curînd în Uniunea Europeană, al cărei imn e o odă închinată bucuriei.”

11 Poème Roumain / Poema Română, symphonic suite for orchestra, Op. 1 (1897) is considered the first genuine work composed by George Enescu in 1897. 
It should be added here Cornel Thăranu's note regarding this charming music: "It is strange that so far none of our orchestras have scheduled it!” (Țăranu, 2017, p. 12)

\subsection{The First National Anthem in Romanian History}

The first musical work, without lyrics, which became our national anthem was Solemn March at the National Flag and His Excellency Prince Ruler (Marș triumfal și primirea steagului și a Măriei Sale Prințul Domnitor). Nowadays, the piece is performed as the official music at Romanian military ceremonies and for the visits of high-ranking foreign dignitaries.

"In 1861, the Romanian Government organized an audition to choose the national anthem. Several musical works were submitted to a special jury. I had the honor to win the prize and shortly thereafter the Romanian Army adopted this winning hymn by official order, on January 22nd, 1862. The orchestral score was published at government expense. To avoid plagiarism or incorrect versions, I took the liberty of including this text as the foreword of my composition, which now has become (the) national (anthem). Signed, Bucharest, November 1862, Eduard A. Hübsch.” (Sîlea, 2006, p. 40) ${ }^{12}$

A few researchers of the history of Romanian music (Poslușnicu, 1928, p. 565; O.L. Cosma, 1976, p. 333; V. Cosma, 1984, pp. 295-301; Sîlea, 2006 pp. 39-41), claim that the music of the Solemn March composed by Eduard Hübsch in 1862, for the above-mentioned contest, is essentially the same as the Romanian Royal Anthem op. 68, signed by Ed. Hübsch, with text by Vasile Alecsandri and officially adopted in 1884 .

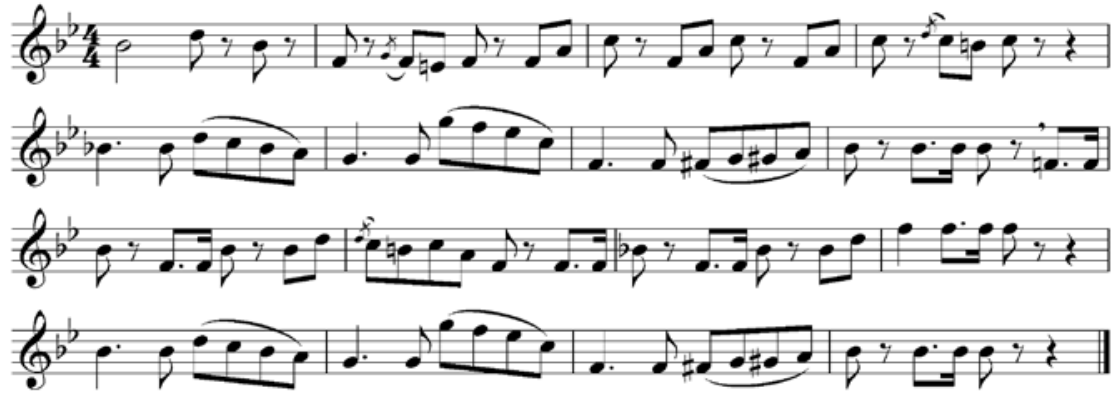

Fig. 5 The Solemn March at the Romanian military ceremonies and at the visits of high ranking foreign personalities

12 „În anul 1861, Guvernul român orânduise un concurs pentru compunerea unui hymn naţional. Mai multe compoziţiuni fură presintate înaintea unei comisiuni speciale. Între toți concurenții, eu am avut onoarea de a obține premiul și puțin timp după aceasta, armata română a adoptat acest hymn premiat de către comisiune, printr-un ordin de zi, cu data de 22 ianuarie 1862 și partițiunea de orchestră a fost publicată pe comptul Guvernului. Spre a evita plagiatul sau reproducțiuni neexacte, îmi iau libertatea de a pune aceste rânduri în capul operei mele ce acum a devenit națională. București, Noiembrie 1872, semnat Eduard A. Hübsch.” 
I enclose below the short description of the Romanian Royal Anthem, published in an anthology of anthems by the prestigious American publisher $G$. Schirmer, Inc., in 1917:

\section{RUMANIAN NATIONAL HYMN}

Rumania came into possession of a national hymn at nearly the same time as Italy. The first move in this direction was merely for the composition of a welcome-fanfare for Prince Alexander Johannes Cusa (1820-1873); in the prize-competition set on foot to this end, in 1861, the victor was Eduard A. Hübsch (1833-1894), military bandmaster at Jassy. The words were written later, when Rumania was raised to a kingdom, by Vasil Alexandri, who adapted them to apply to Karl von Hohenzollern.

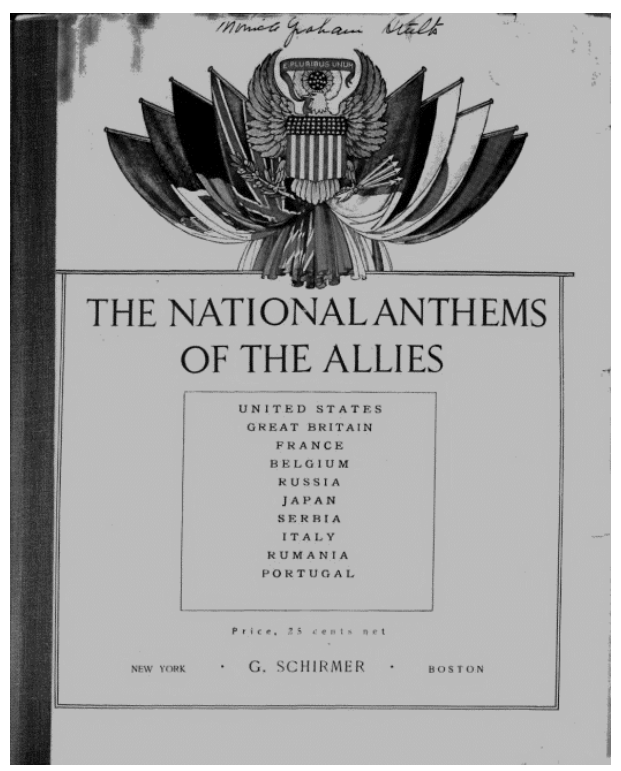

Fig. 6 The Anthem Anthology published by G. Schirmer

Rumania

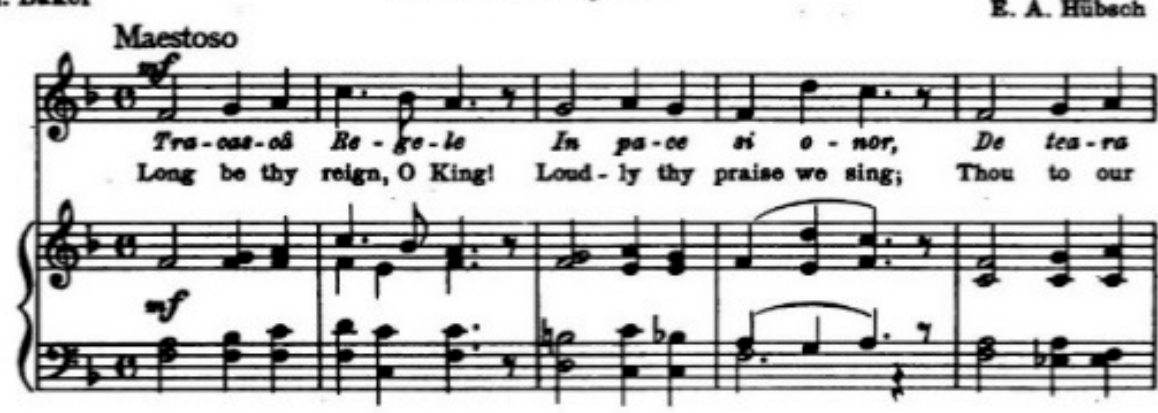



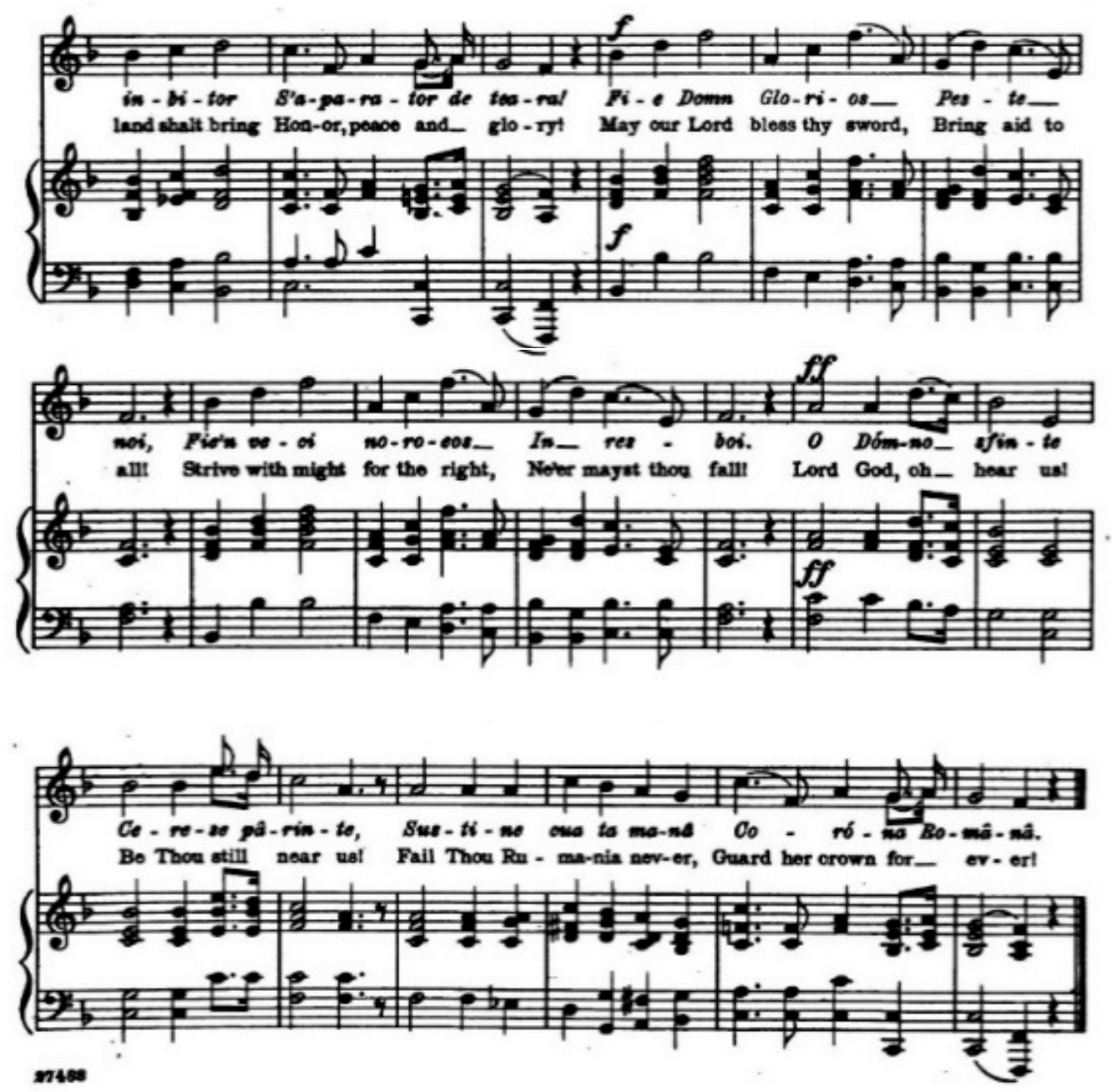

Fig. 7 The Romanian Royal Anthem by Ed. Hübsch (Schirmer, 1922)

This anthem, officially adopted in 1884, was in use until 1947, when the monarchy was abolished in Romania.

Comparing these two hymns (Figs. 5, 7) I am constantly puzzled by claims of their so-called "similarity". Neither of them has the same approach neither melodic, rhythmic, tempo, nor stylistic nature: one is in the style of a March, alert in rhythm and dynamic in character; whereas the other is solemn, slow, and static.

"Since 1861, when Ed. Hübsch was chief lieutenant at the military band of regiment 2, he did compose the Solemn March to be performed in honor of the Prince Ruler and the Flag. In 1884, when this March was transformed into 
the Royal Anthem, with lyrics by Vasile Alecsandri, its tempo became much slower, as hymn tempo.” (Posluşnicu, 1928, p. 565) ${ }^{13}$

What common features the above-mentioned authors had in mind when they purported the kinship between these two musical works remain to be discovered!

The following hymns mark the main periods in the Communist history of Romania.

\subsection{The Anthems of the Communist History of Romania}

The first Romanian Communist anthem was "Broken Handcuffs" (Zdrobite cătușe), music by Matei Socor, with lyrics by Aurel Baranga. It was adopted between 1948 and 1953 (J.V. Stalin's death). The only musical mark to be mentioned is the minor tonality (key) at the beginning.

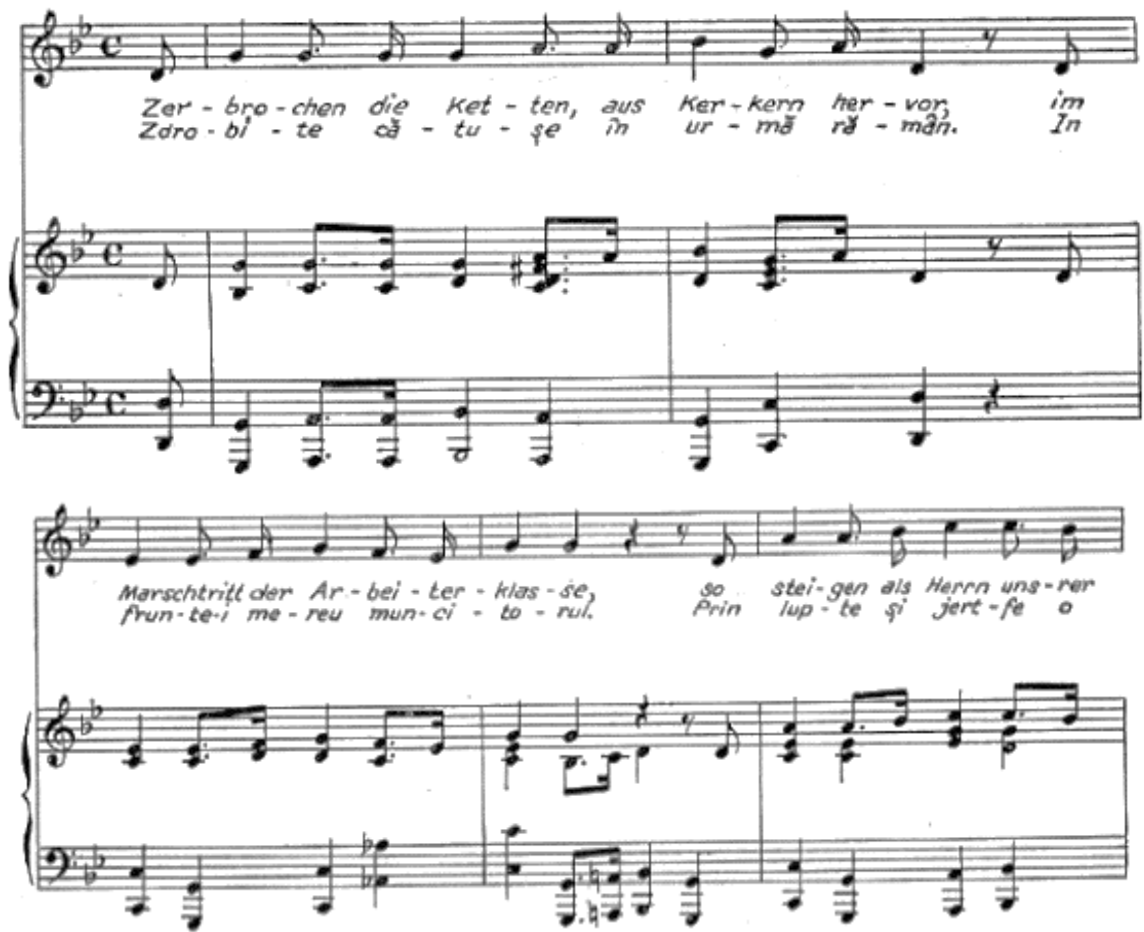

Fig. 8 The very first Romanian communist anthem (excerpt); music by Matei Socor, lyrics by Aurel Baranga

13 ,Încă de pe la 1861, de pe când Ed. Hübsch era încă sublocotenent șef al muzicei regim. 2 de linie, compune «Marșul triumfal», care se executa în tempo de marș de musicile militare, ca Onor la domnitor și steag. Aceasta, până în anul 1884, când, în lipsa unui imn național, acest marş a fost transformat în Imn Regal, la care adaptându-i-se versurile lui Vasile Alecsandri, a luat numirea de «Imn Regal», executându-se pe un tempo mult mai rar, tempo de imn.” 
Regarding the authors, I include here a quotation from the website Nationalanthems.Info:

"Romania's first anthem as a communist republic was introduced January 4, 1948, a few days after the deposition of the monarchy. The anthem was written by Aurel Baranga, a poet and playwright who was widely seen as sympathetic to the communist regime and a collaborator with the government." (www.nationalanthems.info/ro-53.htm)

The next anthem functioned between 1953 and (1975?) 1977: "We praise you, Romania” (Te slăvim, Românie) - music by the same Matei Socor, lyrics by Dan Deșliu.

\section{Solenne}
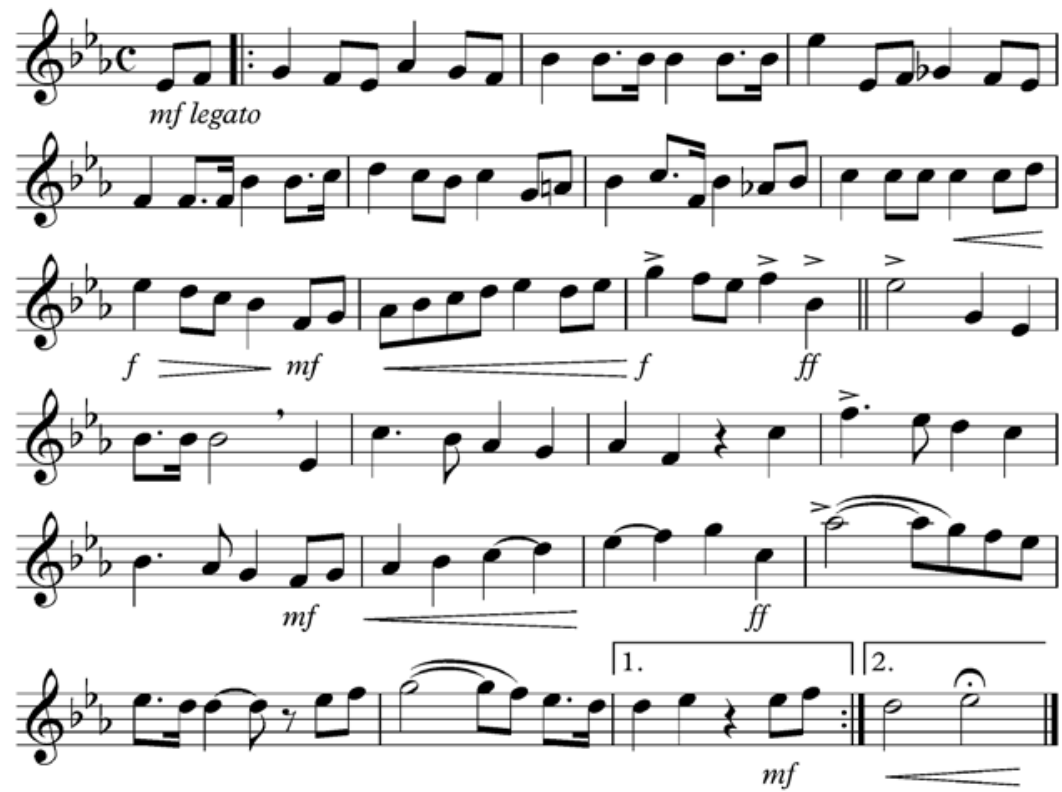

Fig. 9 The song "We praise you, Romania” (Te slăvim, Românie) music by the same Matei Socor

For those who did not live at that time, I quote a single stanza, the one which was eliminated after the 1960's, when diplomatic relations between the USSR and Romania cooled: "May our nation be always fraternal/ With the Soviet people, our liberators./ Leninism is our guiding light, our strength and our enthusiasm,/ We follow with faith the unvanquished party,/ We are creating socialism on our Country's soil." (www.nationalanthems.info/ro77.htm)

\subsection{Ciprian Porumbescu's Hymns}

"In 1975 the Romanian national anthem was changed again. Ceaușescu wanted another hymn, less 'Stalinist'. So Romanians began to 
sing Ciprian Porumbescu's “On our Flag Union is Written” (Pe-al nostru steag e scris Unire) or "Anthem of the Union" (Imnul Unirii) ${ }^{14}$. Afterwards, at the suggestion of the poet Victor Eftimiu, of Albanian origin, the melody became the Albanian national anthem." 15 First, historical sources state that the Albanian national anthem was officially adopted in 1912, not in 1977, as the quoted television report mentions. The musicologist Viorel Cosma offers further information: "Scînteia journal No. 10379, from January 4th, 1975, published the adapted lyrics of Ciprian Porumbescu's 'On our Flag Union is written'...” (V. Cosma, 1984, p. 302) No source mentions the official change of the Romanian anthem. Even though there is no certainty, I considered it appropriate to include this hymn among the historical Romanian anthems for its music of undeniably expressive value - to my thinking more valuable than other hymns that have been historically confirmed!

Ciprian Porumbescu's “Anthem of the Union" was included in a collection of songs published in Vienna. "In February 1880, The Collection of social songs for Romanian students, composed and dedicated to Romanian academic youth by Ciprian Golembiovschi-Porumbescu student at Vienna Conservatory was published.” (Cionca, 1974, p. 86)

"The songs are simple - wrote the composer -, the airs are melodic and the lyrics too; they are not difficult to learn for anyone, even if not professional - that was my goal. The melodies are written for one voice only; one rehearsal and some musical talent could ensure the accompaniment of that voice. /.../ Hoping that my little opus will be happily received by Romanian young people, I think I have contributed a little to the development of social spirit among Romanian students." ${ }^{16}$ (Cionca, 1974, p. 87)

\footnotetext{
14 The first title was The Romanian Youth Hymn; it was probably composed in 1879. (Cionca, 1974, pp. 86-90)

15 „În anul 1975, imnul național al României a fost din nou schimbat. Ceaușescu și-a dorit o altă melodie, mai puțin stalinistă. Așa au ajuns românii să cânte Pe-al nostru steag e scris Unire, pe muzica lui Ciprian Porumbescu. Melodia a devenit ulterior imnul naţional al Albaniei, la propunerea poetului Victor Eftimiu, de origine albanez." Quotation from the TV Show The Anthem Story. Romania had six national anthems. How appropriate is 'Deșteaptăte, române!'? (POVESTEA IMNULUI. România a avut şase imnuri de stat. Cât de reprezentativ este „Deșteaptă-te, române”?) of TV Chanel DIGI 24.

16 „Cântecele sunt simple, ariile sunt melodice și, ca și poeziile, fără multă măiestrie și artă, pentru ca fiecare, fie și neexpert în muzică, să și le poată uşor însuşi, e este chiar scopul meu. Melodiile sunt acomodate numai pentru o voce; însă o singură repetare presupunând și puțin auz muzical, poate asigura acompanierea acelei voci. /.../ Sperând că micul meu op. va avea o călduroasă îmbrățișare în sânul junimii române, cred a contribui cât de puțin la înaintarea şi prosperarea spiritului social între studenții români." Excerpt from the foreword signed by the composer at the Collection of social songs
} 
The author's modest hope, expressed in the preface of the collection, has long been achieved, as the hymn became a symbol not only for the historical moment to which it was dedicated, but also for the Romanian spirit itself, typical in the romantic atmosphere of the 19th century. More than that: the music with Albanian lyrics became the national anthem of Albania in 1912. Finally, between 1975 and 1977, this song was the anthem of communist Romania as well.

The song has a simple, bright melody, in March style, in a major key. The beginning of the second part, in piano, anticipates and increases the climax.

It is an example of music in which expressivity and spontaneity are accomplished by means of simplicity, logic, and naturalness of construction. This explains the success that this hymn has earned since it first appeared.

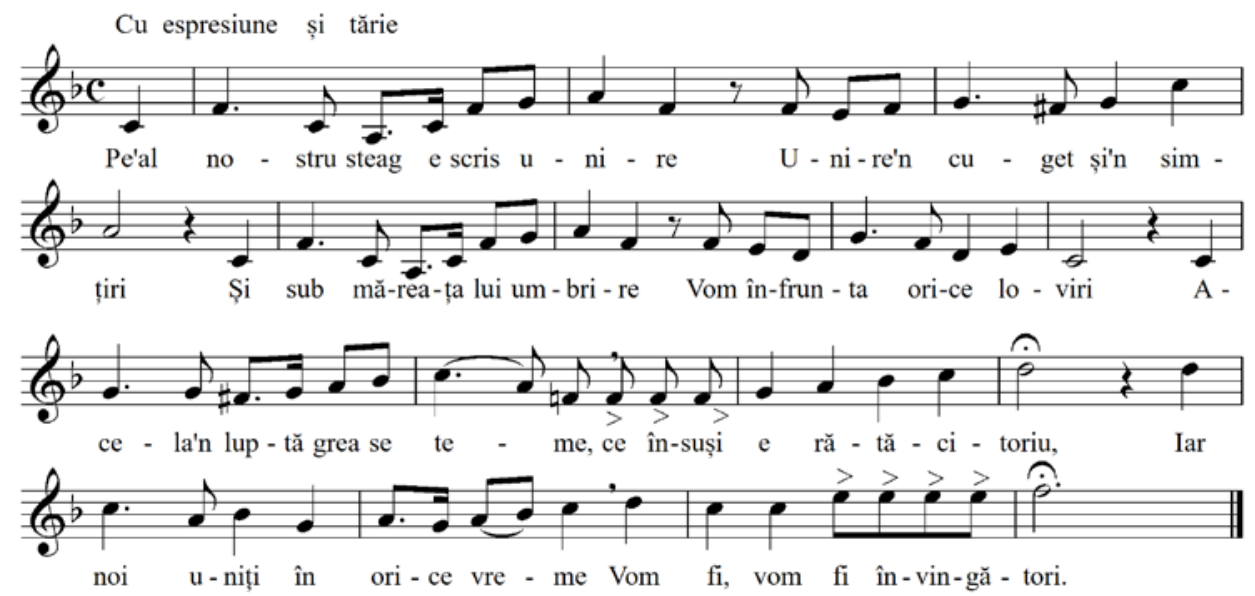

Fig. 10 Ciprian Porumbescu’s “Anthem of the Union”
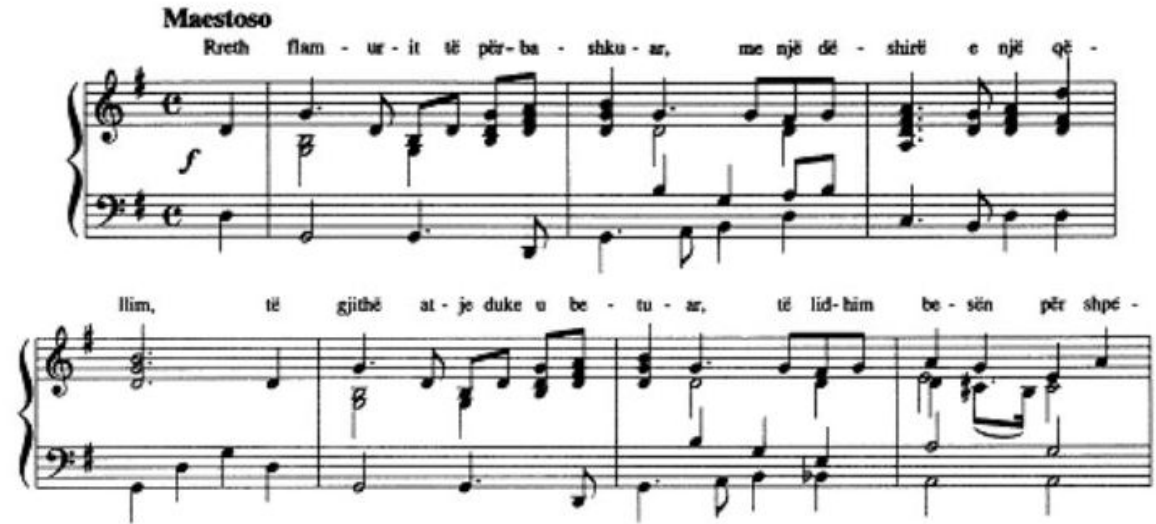

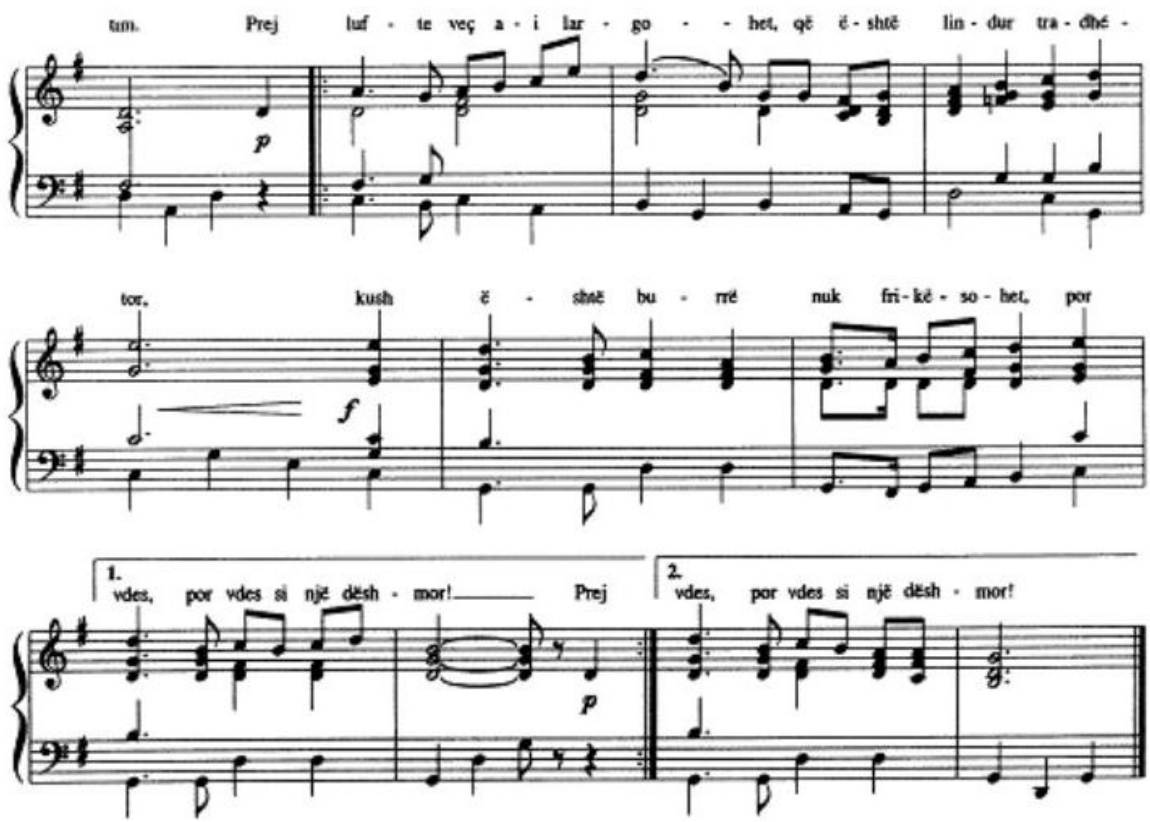

Fig. 11 National Anthem of Albania

The last anthem of communist Romania (unjustly blamed after 1989) ${ }^{17}$ is “Three Colors", music and lyrics by Ciprian Porumbescu.

As with the "Anthem of Unity", "Three Colors" is included in The Collection of Social Songs for Romanian students, Composed and Dedicated to Romanian Academic Youth, published by Ciprian Porumbescu in 1880 in Vienna. The musician created the lyrics as well. In 1977, Nicolae Ceaușescu signed the decree designating Ciprian Porumbescu's music as the national anthem. As a result of paranoia, the dictator of Socialist Romania decided to change the text, "for the National Anthem of the Socialist Republic of Romania has to include the idea of protecting the homeland, also that of the Romanian people's foreign policy for peace and friendship.” (Decret / Decree nr. 420, 1977)

${ }^{17}$ It's about Romanian people's post-revolutionary attitude of blaming all communist symbols, including language spelling and national anthem. 


\section{IMNUL DE STAT \\ AL REPUBLICII SOCIALISTE ROMÂNIA}

Muzica de Ciprian Porumbescu

Maestoso

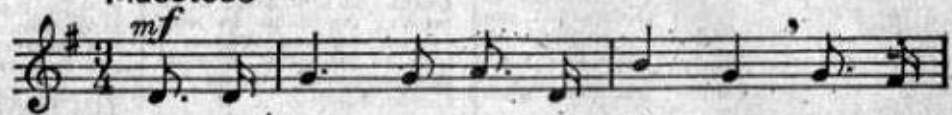

1. Trei cu-lori cu-nosc pe lu - me, A-min-

2. Mul - te se - co - le lup - ta - rá Strā - bu -

3. Ro - șu, gal - ben și al - bas - tru Es - te-al

4. Sin-tem un po-por in lu - me Strins u-

5. Azi par-ti - dul ne u - nes - te, Si pe

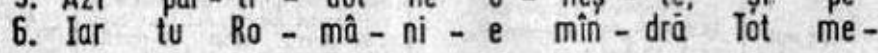

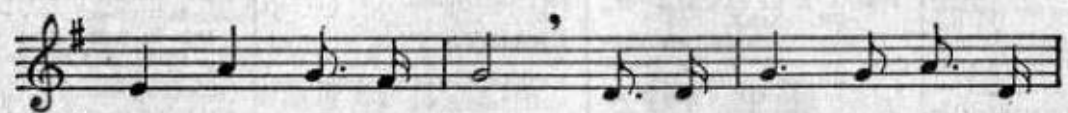

tind de-un brav po - por, E vi - teaz, cu vechi re -

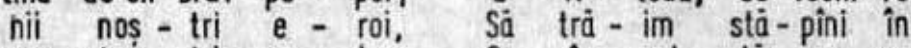

nos - tru tri- $\mathrm{CO}$ - lor, $\mathrm{Se} \hat{i}-\mathrm{nal}-\mathrm{tạ}$ ca un

nit si. mun-ci - tor Li-ber, cu un nou re -

pla iúl ro-mâ-nesc $\quad S_{0}$ - cia - lis - mul se clä-

reu sá. däi-nu-iești Şi în $c 0-m u-n i s-t a$

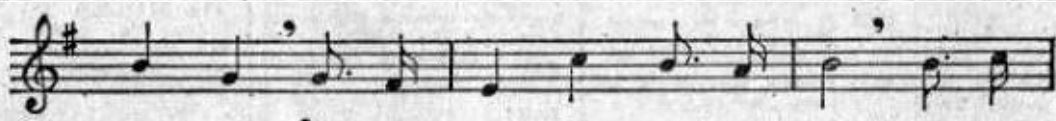

nu - me, In lup - tà tri - um-fä-tor, ' E vi -

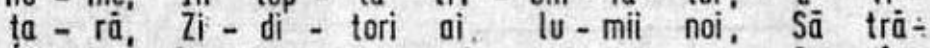

as - tru Gla - ri - o - sul meu po-por, Se i -

nu - me Și un tel cu - te - zā - tor. Li-ber.

deș-te Prin e - Ian mun - ci - to - resc, So- cia

e - rá Ca 0 stea sà štrā-lu-cești Și î̀.

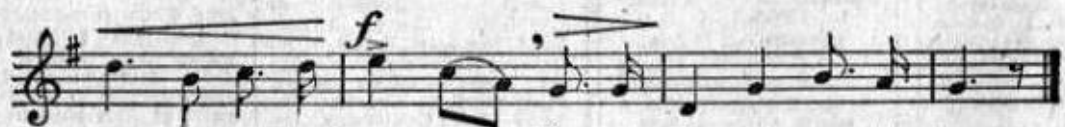

teaz, cu vechi re - nu-me, I In lup - tà tri - um-fà - tor.

im stä-pîni în ta-râ,__ Zi-- di-tori ai lu-mii noi.

nal- tâ ca un as-tru_Glo-ri-o-sul meu po-por.

cu un nou re-nu-me_si un tel cu-te-zä-tor.

lis-mul se clä-deș-te__ Prin e lan mun-ci-to-resc.

co-mu-nis-ta e - rá_- Ca o stea sä- strä-lu-cești.

Fig. 12 National Anthem of communist Romania, between 1977 and 1989, music by Ciprian Porumbescu, lyrics changed

Not to mention the lack of correspondence between the musical and the phonetic accents of the new stanzas:

Wrong: În lup-tă triumfător $\quad$ Correct: În lup-tă triumfător 
The genuine version of the hymn, with poetic and historical value, was thus replaced by another one full of slogans, fictitious and histrionic.

Unfortunately, after 1989, many Romanian people let loose some of their anger on the most unexpected things and ideas: agricultural irrigation pipes in the fields, books, vocabulary and among the first, the communist anthem! At that time, we took revenge on form - in fact we agreed on formal changes, without noticing how many insidious traits and ideas remained perpetuated in the background! In those days of rage, who was able to think of how the true verses of Ciprian Porumbescu's song sounded: true romantic pathos, conceived with all conviction and feeling?! Who then dared to claim that this music of indisputable purity, clarity and accessibility was just as appropriate to the genre of the symbol-song as the best national anthems in the world. We therefore sacrificed the music for some lyrics and we felt freer!

\section{Conclusions}

Why did I start this investigation? The answer is short and definite: I wanted to express my opinion regarding our national anthem "Awaken, Romanian!” Almost every live performance awakens (!) in me peculiar sensations, in any case not the most favorable.

The Enlightenment penetrated (deeper or more superficially, faster or slower) into all European cultural areas, from East to West. In the 18th century, it planted and fed all over Europe the seeds of spirit of nationalism that invaded and dominated the 19th century. This is how I basically explained to myself the time and place of the emergence of the spirit of nationalism in the history of Europe.

Among the features that gave birth to nationalism, along with folklore, language, cultural-geographic space, there are the national symbols - including patriotic songs -, most of them designated together with the creation of the concept of nationhood, during the 19th century.

The history of the last two hundred years now shows that a national anthem could be assigned in many but not unlimited circumstances; of primary importance should be the music. Judging from many examples, it becomes clear that anthems usually consist of specific musical features. I found that in most cases the music is tonal, major key, mostly consonant, with short, simple melodies, so that most people can sing it.

Other circumstances are provided by history: when, where, through whose contribution the anthem was chosen - sometimes these circumstances become more important than the music itself.

Now it is inconceivable that anyone would ask for Deșteaptă-te, române! /“Awaken, Romanian!” to be removed from the national repertoire. The song 
carries profound historical and emotional meaning for Romanians, along with genuine musical value. Nevertheless, the Romanian patriotic repertoire is so vast, with enough historical and musical values, that it would not be difficult to choose a hymn appropriate both to our history and to our times. Such a song could be Pui de lei / "Young Lions", composed by Ionel Brătianu ${ }^{18}$, in 1902, lyrics by Ioan Nenițescu.

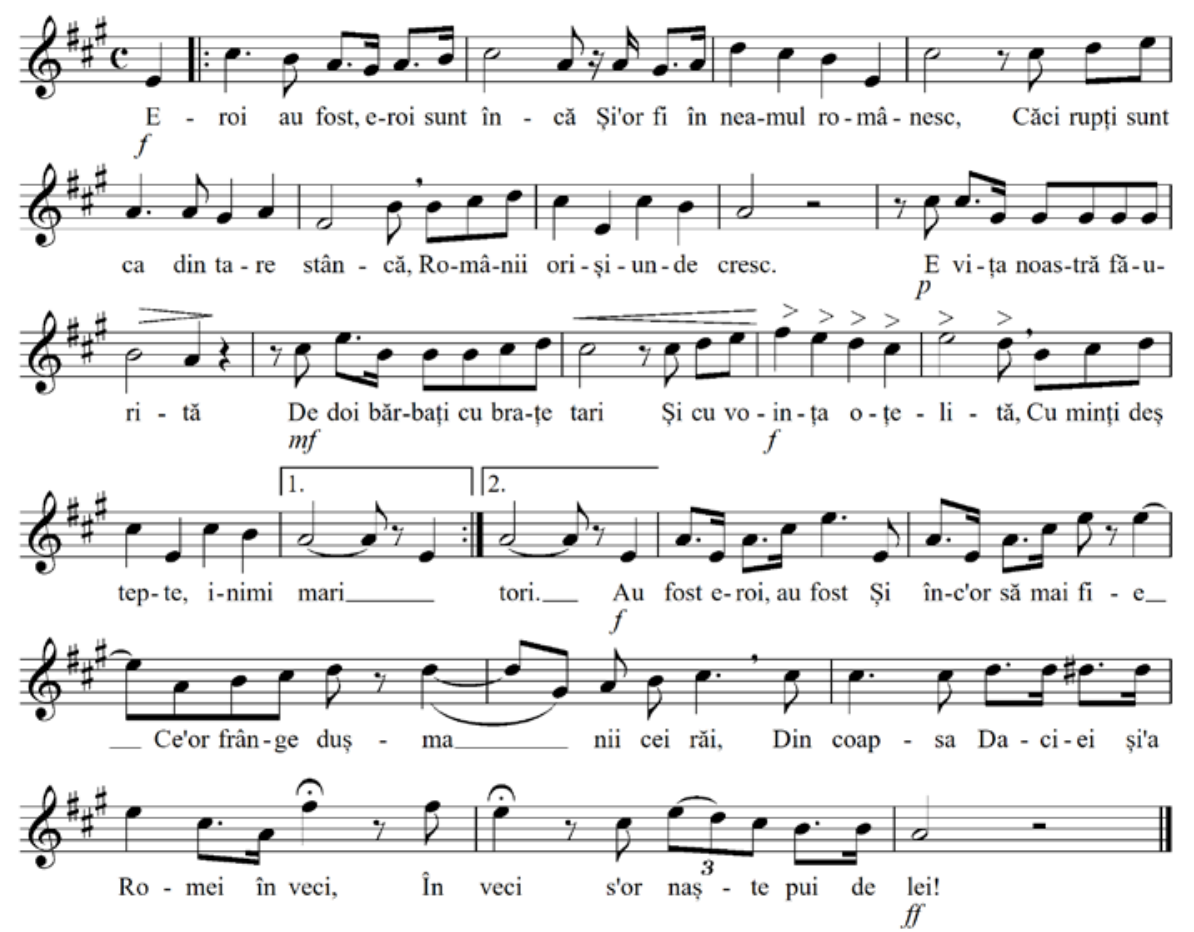

Fig. 13 The song Pui de lei (Young Lions) by Ionel Brătianu and Ioan Nenițescu

This song has the necessary features of such a destination: tune easy to sing, major key, dotting rhythm (generating dynamism), and climax to the end, which gathers the whole force of the musical discourse. Furthermore, following Andrei Pleșu' statement, the lyrics are bright, optimistic, without death, curse, blood, and torment - lyrics that sum up both the past, the present and the future of Romanians.

${ }^{18}$ Ionel Brătianu, 1885-1921, born in Bucharest, composer and conductor, son of the musician Gheorghe Brătianu. He studied first with his father, then at Bucharest Conservatory, with Dumitru Georgescu-Kiriac (music theory), Eduard Wachmann (harmony), Robert Klenck (violin). Works: opera, symphonic, chamber and choral music. (V. Cosma, 1989, pp. 178-180). 
They were heroes, they're still heroes, And they are in the Romanian nation! Cause they're broken like of a hard rock, Romanians are growing up everywhere.

Our nation is made

By two people with strong arms

And with strong volition

With smart minds, big hearts.
One is the industrious Decebal And the other the smart Trajan. Eh, for their hearth, bitter They fought with many enemies.

And of good parents Every time heroes will be born. What for their mother nation Will always be winners.

They were heroes, and they will be, What will bring down the bad enemies. From the Dacia's and Rome's coast Every time young lions will be born.

Therefore, I wonder: why is this song not the national anthem of contemporary Romania - loaded with historical significance, authentic musical inspiration and appropriate lyrics?

\section{References}

Boia, L. (2012). Două secole de mitologie națională [Two Centuries of National Mythology]. București: Humanitas.

Chelaru, C. (2017). Required Dichotomies in the Romanian (Music) History. Saarbrücken: Lambert Academic Publishing.

Chelaru, C. (2017). Cântecul-simbol, istorie și conținut. Despre imnurile naționale [The Song-Symbol, History and Content. About the National Anthems]. București: Editura Muzicală.

Cionca, N. (1974). Ciprian Porumbescu. București: Editura Muzicală.

Cosma, O. L. (1976). Hronicul muzicii românești [Romanian Music Chronicle], vol. IV. București: Editura Muzicală.

Cosma, V. (1984). Exegeze muzicologice [Musicological Exegesis]. București: Editura Muzicală.

Cosma, V. (1989). Muzicieni din România. Lexicon [Musicians from Romania. Lexicon], vol. I. București: Editura Muzicală.

Gay P. (1996). The Enlightenment: An Interpretation. W. W. Norton \& Company. Retrieved from www.wikipedia.ro

Pann, A. (2009). Spitalul amorului sau Cîntătorul dorului [The Hospital of Love or the Singer of Longing]. București: Editura Compania. 
Pascu, Cr. (2015). Lucrări enesciene în primă audiție absolută pe scena clujeană [Works by Enescu on international premiere at 'Academia de Muzică' from Cluj]. Făclia, independent Journal. Cluj, November 25

Pleșu, A. (2011). Psihologia imnului national [The National Anthem’s Psychology]. Dilema Veche, 397, 22-28 September.

Poslușnicu, M. Gr. (1928). Istoria muzicei la români[Romanian History of Music]. București: Editura Cartea Românească.

Sîlea, M. (2006).Istoria muzicilor militare [History of Military Music]. București: Editura Militară.

Ștefănescu, M. (1974). Cîntecul revoluționar și patriotic românesc [The Revolutionary and Patriotic Romanian Song]. București: Editura Muzicală.

Țaranu, C. (2017). Enescu, nouvelles restitutions. Proceedings of the "George Enescu” International Musicology Symposium: "George Enescu, from Knowledge to recognition”, Bucharest, Romania, September 3-4, 102-103. București: Editura Muzicală.

*** Decret nr. 420 din 17 noiembrie 1977, privind completarea Legii nr. 33/1977 [Decree No. 420 from November 17, 1977, on completing the Law No. 33/1977] in Buletinul Oficial [The Official Bulletin], 120, 18 noiembrie 1977.

*** (c1917), The National anthems of the Allies: United States, Great Britain, France, Belgium, Russia, Japan, Serbia, Italy, Rumania, Portugal. New York: G. Schirmer.
*** www.corneltaranu.com
*** www.dolmetsch.com
*** www.merriam-webster.com
*** nationalanthems.info 